\title{
KEGIATAN BERCERITA DENGAN BUKU CERITA BERGAMBAR DALAM UPAYA MENINGKATKAN KEMAMPUAN BERBAHASA PADA ANAK USIA DINI KELOMPOK B TK AL FALAH KOTA JAMBI
}

\author{
Suryani \\ TK Negeri Pembina I Kota Jambi \\ Email suryani.yani.1964@gmail.com
}

\begin{abstract}
ABSTRAK
Penelitian ini bertujuan untuk meningkatkan kemampuan membaca dengan menggunakan media kartu huruf pada anak kelompok B di TK PertiwiII Kota Jambi. Kemampuan membaca yang ditingkatkan ialah menyebutkan Penelitian ini dilakukan karena adanya permasalahan dalam kemampuan membaca awal di kelompok B. Jenis penelitian ini adalah penelitian tindakan kelas (classroom action research) yang dilakukan secara kolaboratif antara peneliti dengan guru kelas.

Subjek penelitian ini sebanyak 17 anak. Obyek penelitian dalam penelitian ini adalah peningkatan kemampuan mengenal huruf menggunakan media kartu kata. Metode pengumpulan data dilakukan melalui observasi dan wawancara. Instrumen penelitian yang digunakan dalam penelitian ini yaitu instrumen observasi daftar cek (check List).Teknik analisis data yang digunakan yaitu teknik deskriptif kuantitatif.

Berdasarkan hasil penelitian dan pembahasan dalam penelitian ini dapat disimpulkan bahwa kemampuan membaca anak kelompok B di TK Pertiwi II Kota Jambi dapat ditingkatkan menggunakan media kartu huruf dalam proses pembelajaran permainan tebak huruf pada kartu angka dengan cara masingmasing anak membawa/memegang kartu angka secara langsung dan memainkannya sesuai instruksi guru yaitu menyebutkan huruf, menunjukkan huruf, dan menghubungkan huruf. Hasil penelitian menunjukkan bahwa ada peningkatan kemampuan membaca awal yaitu pada kondisi awal sebesar 29,2\% meningkat pada Siklus I menjadi 58,3\% , dan Siklus II meningkat sebesar 83,3\%.
\end{abstract}

Kata kunci: Metode Pembelajaran, Anak Usia Dini, Cerita Bergambar

\section{A. PENDAHULUAN}

\section{Latar Belakang}

Pendidikan merupakan salah satu upaya yang dapat dilakukan manusia untuk dapat mengembangkan kemampuan yang dimilikinya. Melalui pendidikan manusia akan memperoleh beberapa pengetahuan dan keterampilan-keterampilan hidup. Pendidikan juga harus memperhatikan layanan yang diberikan kepada anak 
didiki, bukan sekedar menyampaikan pengetahuan tetapi menanamkan nilai-nilai kepada anak didik dengan proses pembelajaran yang bermutu.(Sumarto, 2018) Oleh karena itu pelaksanaan pendidikan perlu mendapatkan perhatian agar dapat berjalan optimal, terutama pendidikan untuk anak usia dini.

Pendidikan Anak Usia Dini (PAUD) adalah suatu upaya pembinaan yang ditujukan kepada anak sejak lahir sampai pada usia enam tahun yang dilakukan dengan memberikan rangsangan pendidikan untuk membantu perkembangan jasmani dan rohani agar anak memiliki kesiapan dalam memasuki pendidikan lebih lanjut (UU No. 20 Th 2003, pasal 1 ayat 14 tentang Sisdiknas).

Pendidikan anak usia dini penting dilaksanakan sebab anak usia 0-6 tahun berada pada masa peka yaitu masa dimana seluruh potensi anak dapat dikembangkan secara optimal baik dalam aspek fisik, bahasa, kognitif, sosialemosional, maupun moral-agama. Permendiknas No. 58 tahun 2009 tentang Standar Pendidikan Anak Usia Dini menyebutkan bahwa pendidikan anak usia dini dilaksanakan melalui tiga jalur pendidikan yaitu pendidikan formal, non formal dan informal.

Taman kanakkanak termasuk dalam jalur pendidikan non formal. Menurut M. Ramli (2005: 185) masa usia Taman Kanak-kanak (TK) merupakan masamasa kehidupan manusia dengan rentang usia empat sampai enam tahun. Pada usia 0-6 tahun anak perlu mendapatkan stimulasi yang tepat agar seluruh aspek perkembangan anak dapat berkembang optimal, baik aspek kognitif, bahasa, fisik-motorik, moral agama maupun aspek sosial emosionalnya.

Kelima aspek perkembangan tersebut tidak dapat dipisahkan satu dengan yang lainnya. Meskipun demikian bahasa memiliki peran yang sangat penting dalam tumbuh kembang anak terutama dalam membantu seseorang untuk berinteraksi dan berkomunikasi dengan orang lain. Anak dapat mengungkapkan segala keinginannya maupun ide-idenya kepada orang lain, hal ini mempengaruhi perkembangan anak. Bahasa akan membantu anak untuk memperoleh pengetahuan-pengetahuan baru dari berinteraksi dengan orang lain tersebut.

Bachtiar Bachri (2005: 4) mengelompokkan pengembangan bahasa menjadi dua yaitu; mendengar dan berbicara, serta membaca dan menulis. Hal ini 
juga dikemukakan oleh Soemiarti Patmonodewo (2003: 29) yakni terdapat dua daerah pertumbuhan bahasa yaitu bahasa yang bersifat pengertian atau reseptif yang meliputi mendengar dan membaca; serta bahasa yang bersifat pernyataan atau ekspresif yang meliputi berbicara dan menulis.

Kemampuan berbahasa khususnya kemampuan membaca dan menulis pada anak usia TK tidak sama dengan kemampuan membaca dan menulis usia dewasa. Kemampuan membaca dan menulis anak menurut Slamet Suyanto (2005b: 168) masih pada tahap membaca dan menulis permulaan. Pada tahap permulaan ini anak membutuhkan berbagai stimulasi untuk membaca dan menulis permulaan, misalnya saja pengetahuan tentang huruf-huruf alfabet, berbagai gambar yang menarik untuk menstimulasi anak mengenal simbol-simbol dan lain sebagainya.

Pendidikan Taman Kanak-Kanak merupakan salah satu bentuk pendidikan pra sekolah yang terdapat di jalur pendidikan sekolah (PP No. 27 Tahun 1990). Sebagai lembaga pendidikan pra-sekolah, tugas utama Taman Kanak-Kanak adalah mempersiapkan anak dengan memperkenalkan berbagai pengetahuan, sikap perilaku, keterampilan dan intelektual agar dapat melakukan adaptasi dengan kegiatan belajar yang sesungguhnya di Sekolah Dasar.

Pandangan ini mengisyaratkan bahwa Taman Kanak-Kanak merupakan lembaga pendidikan pra-sekolah atau pra-akademik. Dengan demikian Taman Kanak-Kanak tidak mengemban tanggung jawab utama dalam membina kemampuan akademik anak seperti kemampuan membaca dan menulis. Substansi pembinaan kemampuan akademik atau skolastik ini harus menjadi tanggung jawab utama lembaga pendidikan Sekolah Dasar.

Alur pemikiran tersebut tidak selalu sejalan dan terimplementasikan dalam praktik kependidikan Taman Kanak-Kanak dan Sekolah Dasar di Indonesia. Pergeseran tanggung jawab pengembangan kemempuan skolastik dari Sekolah Dasar ke Taman Kanak-Kanak terjadi di mana-mana, baik secara terang-terangan maupun terselubung. Banyak Sekolah Dasar seringkali mengajukan persyaratan atau tes "membaca dan menulis". Lembaga Pendidikan Sekolah Dasar seperti ini sering pula di anggap sebagai lembaga pendidikan "berkualitas dan bonafide". 
Peristiwa praktik pendidikan seperti itu mendorong lembaga pendidikan Taman Kanak-Kanak maupun orang tua berlomba mengajarkan kemampuan akademik membaca dan menulis dengan mengadapsi pola-pola pembelajaran di Sekolah Dasar. Akibatnya, tidak jarang Taman Kanak-Kanak tidak lagi menerapkan prinsip-prinsip bermain sambil belajar atau belajar seraya bermain, sehingga Taman Kanak-Kanak tidak lagi taman yang indah, tempat bermain dan berteman banyak, tetapi beralih menjadi "Sekolah" Taman Kanak-Kanak dalam makna menyekolahkan secara dini pada anak-anak. Tanda-tandanya terlihat pada pentargetan kemampuan akademik membaca dan menulis agar bisa memasukkan anaknya ke Sekolah Dasar

Mengajarkan membaca dan menulis di Taman Kanak-Kanak dapat dilaksanakan selama batas-batas aturan pengembangan pra-sekolah serta mendasarkan diri pada prinsip dasar hakiki dari pendidikan Taman Kanak-Kanak sebagai sebuah taman bermain, sosialisasi, dan pengembangan berbagai kemampuan pra-skolastik yang lebih substansi yaitu bidang pengembangan kemampuan dasar yang meliputi kemampuan berbahasa atau membaca kognitif, fisik-motorik dan seni.

Mencermati kondisi kegiatan pembelajaran membaca dan menulis di Taman Kanak-Kanak yang berlangsung sebagaimana digambarkan di atas, perlu dilakukan penelitian yang bersifat reflektif dengan melakukan tindakan tertentu yang direncanakan, dilaksanakan dan dievaluasi. Dengan serangkaian tindakan itu diharapkan dapat mengubah suasana pembelajaran ke arah pembelajaran yang lebih memungkinkan siswa terlibat secara aktif dan menyenangkan. Hal itu dapat dicapai dengan melalui pembelajaran menggunakan media gambar. Media gambar adalah penyajian visual 2 dimensi yang dibuat berdasarkan unsur dan prinsip rancangan gambar, yang berisi unsur kehidupan sehari-hari tentang manusia benda-benda, binatang, peristiwa, tempat dan sebagainya (Taufik Rachmat, 1994).

Gambar banyak digunakan guru sebagai media dalam proses belajar mengajar, sebab mudah diperoleh tidak mahal dan efektif, serta menambah gairah dalam motivasi belajar siswa. 


\section{Rumusan Masalah}

1) Bagaimanakah gambaran pembelajaran membaca dengan media gambar di Taman Kanak-Kanak secara klasikal ?

2) Bagaimanakah gambaran pembelajaran membaca di Taman Kanak-Kanak dengan media gambar secara kelompok?

3) Apakah terjadi peningkatan kemampuan siswa dalam membaca setelah mereka mengikuti pembelajaran membaca dan menulis dengan menggunakan media gambar?

\section{Tujuan Penelitian}

1. Menggambarkan pembelajaran membaca di Taman Kanak-Kanak dengan media gambar secara klasikal.

2. Menggambarkan pembelajaran membaca di Taman Kanak-Kanak dengan media gambar secara kelompok.

3. Menemukan terjadinya peningkatan kemampuan siswa dalam membaca setelah menerapkan pembelajaran dengan menggunakan media gambar.

\section{Manfaat Penelitian}

Penelitian ini diharapkan memberikan manfaat bagi :

1) Siswa Taman Kanak-Kanak, agar mereka terbiasa dalam suasana kegiatan pembelajaran di Taman Kanak-Kanak yang menyenangkan dan tidak menakutkan.

2) Bagi guru Taman Kanak-Kanak, dengan penerapan media gambar, guru memperoleh pengalaman baru dalam melaksanakan kegiatan pembelajaran kemampuan berbahasa di Taman Kanak-Kanak yang berpusat pada anak.

3) Bagi peneliti, dapat membantu guru dalam mengatasi masalah dalam pembelajaran kemampuan berbahasa di Taman Kanak-Kanak.

\section{B. LANDASAN TEORI}

1. Pendidikan Anak Usia Dini

Pendidikan Anak Usia Dini atau Early Childhood Education adalah pendekatan pedagogis dalam penyelenggaraan pendidikan anak yang dimulai dari 
saat periode kelahiran hingga usia enam tahun (Danar Santi, 2009: 7). Sedangkan NAECY (National Assosiation Education for Young Children) menyatakan bahwa anak usia dini adalah sekelompok individu yang berada pada rentang usia antara 0-8 tahun (Sofia Hartati, 2005: 7).

Masitoh, dkk (2005: 1) juga mengungkapkan bahwa pendidikan anak usia mencakup berbagai program yang melayani anak dari lahir sampai dengan usia delapan tahun yang dirancang untuk meningkatkan perkembangan intelektual, sosial-emosional, bahasa, dan fisik anak. Pendapat-pendapat tersebut dapat ditegaskan bahwa pendidikan anak usia dini adalah pendidikan yang ditujukan untuk anak usia nol sampai usia delapan tahun.

Pendidikan anak usia dini ini dirancang untuk meningkatkan tumbuh kembang anak mulai dari perkembangan intelektual, sosial-emosional, bahasa serta perkembangan fisik. Semua aspek perkembangan tersebut penting untuk dikembangkan karena antara perkembangan yang satu dengan yang lainnya saling terkait, sehingga harus dilaksanakan secara terpadu.

Pendidikan anak usia dini yang dilaksanakan di Indinesia terdapat beberapa jalur pendidikan. Salah satu jalur pendidikan anak usia dini yang difokuskan dalam penelitian ini adalah pendidikan formal yang berbentuk Taman Kanak-kanak. Anak Usia TK adalah anak yang berusia 4-6 tahun, yang sering 12 disebut juga sebagai masa emas karena peluang perkembangan anak yang sangat berharga (Rosmala Dewi, 2005: 1). Masitoh, dkk (2005: 7) mengungkapkan bahwa anak usia TK sering disebut sebagai "the golden age" atau masa emas yang berarti bahwa masa ini merupakan fase yang sangat fundamental bagi perkembangan dimana kepribadian dasar individu mulai terbentuk. Menurut Mayke Sugianto (1995: 1-2) usia TK atau prasekolah adalah anak usia antara tiga sampai lima atau enam tahun yang merupakan masa awal yang penting untuk perkembangan anak baik aspek psikososial, fisik motorik serta kecerdasan.

Pendidikan Taman Kanak-kanak dengan kisaran usia antara 4 sampai dengan 6 tahun ini di Indonesia diselenggarakan ke dalam dua kelompok yaitu kelompok A usia 4-5 tahun dan kelompok B usia 5-6 tahun (Harun Rasyid, 2009: 45). Hal ini diatur dalam Permendiknas No 58 tahun 2009 halaman 5 yang 
membagi usia pra-sekolah dalam kelompok usia yaitu usia 4-5 tahun yang disebut kelompok A dan usia 5-6 tahun yang disebut kelompok B. Sofia Hartati (2005: 8) membagi anak usia dini berdasarkan pertumbuhan dan perkembangannya menjadi beberapa kelompok yaitu (1) kelompok bayi pada usia 0-12 bulan; (2) kelompok bermain pada usia 1- 3 tahun; (3) kelompok pra sekolah pada usia 4-5 tahun dan; (4) kelompok usia sekolah pada usia 6-8 tahun.

Pendapat-pendapat di atas dapat ditegaskan bahwa anak usia dini adalah anak yang berada pada rentang usia 0-6 tahun yaitu masih pada tahap usia prasekolah dimana pada tahap ini penting untuk mengembangkan seluruh potensi yang dimiliki anak karena anak pada masa peka. Masa peka adalah masa dimana perkembangan kemampuan anak mulai dari bahasa, kognitif, fisik motorik, sosial 13 emosional dan moral agamanya dapat dikembangkan secara optimal sehingga diperlukan stimulasi yang tepat. Anak usia 4-6 tahun sudah masuk dalam kelompok pendidikan nonformal yaitu Taman Kanak-kanak.

Pada usia ini diperlukan pembelajaran yang tepat agar anak memiliki kesiapan untuk belajar di jenjang berikutnya. Anak Taman Kanak-kanak tersebut dibagi dalam 2 kelompok usia yaitu usia 4-5 tahun yang disebut kelompok A dan usia 5-6 tahun yang disebut kelompok B.

Bahasa merupakan alat komunikasi utama bagi seorang anak untuk mengungkapkan berbagai keinginan maupun kebutuhannya. Anak-anak yang memiliki kemampuan berbahasa yang baik pada umumnya memiliki kemampuan yang baik pula dalam mengungkapkan pemikiran, perasaan serta tindakan interaktif dengan lingkungannya. Kemampuan berbahasa ini tidak selalu didominasi oleh kemampuan membaca saja tetapi juga terdapat sub potensi lainnya yang memiliki peranan yang lebih besar seperti penguasaan kosa kata, pemahaman (mendengar dan menyimak) dan kemampuan berkomunikasi.

\section{Media Pembelajaran}

Kata media berasal dari bahasa latin medius yang berarti "tengah", "perantara" atau "pengantar". Dalam bahasa Arab, media adalah perantara atau pengantar pesan dari pengirim kepada penerima pesan.Menurut Association of 
Education and Communication Technology (AECT, 1977) media merupakan segala bentuk dan saluran yang digunakan orang untuk menyalurkan pesan/informasi (Ashar Arsyad, 2002: 3). Menurut Gerlach \& Ely bahwa media secara garis besar adalah manusia, materi, atau kejadian yang membangun kondisi siswa memperoleh pengetahuan, keterampilan, atau sikap. Secara lebih khusus, pengertian media dapat diartikan alat-alat grafis, fotografis, atau elektronis untuk menangkap, memproses, dan menyusun kembali informasi visual dan verbal. (Ashar Arsyad, 2002: 3) Menurut Gagne (1970) media didefinisikan sebagai berbagai jenis komponen dalam lingkungan siswa yang dapat merangsangnya untuk belajar.

Arif S.Sadiman. (1993) memberikan pengertian media sebagai segala sesuatu yang dapat digunakan untuk menyalurkan pesan dari pengirim ke penerima sehingga dapat merangsang fikiran, perasaan, perhatian dan minat serta perhatian siswa sedemikian rupa sehingga proses belajar terjadi. Media instruksional atau media pembelajaran selalu terdiri dari dua unsur pokok yaitu unsur peralatan atau perangkat keras (hardware) dan unsur pesan yang dibawanya (message/software). Unsur pesan adalah informasi atau bahan ajar dalam tema/ topik tertentu yang akan disampaikan atau dipelajari.

Sedangkan 17 unsur perangkat keras adalah sarana atau peralatan yang digunakan untuk menyampaikan pesan tersebut. Dengan demikian, sesuatu baru dapat dikatakan sebagai media pembelajaran jika sudah memenuhi dua unsur tersebut. (Badru Zaman dkk, 2008: 4.5)

Dari berbagai definisi dari media di atas, dapat diambil kesimpulan bahwa media adalah segala sesuatu dalam lingkungan siswa dan merupakan non personal (bukan manusia) yang dapat digunakan untuk menyalurkan pesan atau isi pelajaran sehingga dapat merangsang pikiran, perasaan, perhatian dan kemampuan siswa dalam proses belajar mengajar. Jadi, media pembelajaran adalah media yang digunakan pada proses pembelajaran sebagai penyalur pesan antara guru dan siswa agar tujuan pengajaran tercapai.

Media pembelajaran yang baik harus memenuhi beberapa syarat. Penggunaan media mempunyai tujuan memberikan motivasi kepada siswa. Selain 
itu media juga harus merangsang siswa mengingat apa yang sudah dipelajari selain memberikan rangsangan belajar baru. Media yang baik juga akan mengaktifkan siswa dalam memberikan tanggapan, umpan balik dan juga mendorong siswa untuk melakukan praktik dengan benar.

Manfaat media Secara umum, manfaat media dalam proses pembelajaran adalah memperlancar interaksi antara guru dan siswa sehingga kegiatan pembelajaran akan lebih efektif dan efisien. Tetapi secara khusus ada beberapa manfaat media 18 yang lebih rinci.

Secara umum media mempunyai kegunaan seperti:

1) Memperjelas penyajian pesanagar tidak terlalu verbalistis,

2) Mengatasi keterbatasan ruang, waktu dan daya indera,

3) Penggunaan media secara tepat dan bervariasi dapat mengatasi sikap pasif anak,

4) Sifat unik anak dan lingkungan berbeda penggunaan media untuk memberi perangsang yang sama, mempersamakan pengalaman, meninbulkan persepsi sama (Arif S Sadiman dkk, 2006: 12-18).

\section{METODE PENELITIAN}

\section{- Subjek Penelitian}

Subjek penelitian adalah subyek dari mana data diperoleh (Suharsimi Arikunto, 2006: 129). Subjek penelitian dalam penelitian ini adalah siswa Kelompok B TK yang berjumlah 15 siswa.

\section{- Desain Penelitian}

Proses Penelitian Tindakan Kelas Model Penelitian Tindakan Kelas Kemmis \& Mc. Taggart (Suharsimi Arikunto, 2006: 93).

1. Rencana/planning Hal-hal yang dilakukan dalam tahap perencanaan adalah sebagai berikut:

a. Penyusunan rencana diawali dengan observasi mengenai berbahasa siswa Kelas B TK Al Falah Kota Jambi.

b. Merumuskan rencana tindakan yang akan dilakukan, dengan mempertimbangkan keadaan dan suasana obyektif dan subyektif. Dalam 
perencanaan tindakan tersebut tertuang mengenai kegiatan guru, kegiatan siswa, dan kegitan observer dalam proses pembelajaran, media yang harus disiapkan, ruang kelas dan alokasi waktu yang tersedia.

c. Menyiapkan rancangan pembelajaran dengan media kartu kata. Rencana kegiatan Harian (RKH) terlampir.

d. Menyiapkan pedoman observasi dan format observasi

e. Menyiapkan instrumen penilaian

f. Perencanaan tersebut didiskusikan dengan Guru yang lain untuk memperoleh masukan.

\section{- Teknik Pengumpulan Data}

Teknik pengumpulan data adalah cara yang digunakan peneliti untuk mengumpulkan data (Suharsimi Arikunto, 2003: 134). Berbagai metode penelitian antara lain: angket, wawancara/interview, pengamatan, ujian atau tes, dokumentasi dan sebagainya. Teknik pengumpulan data (observasi ) dan wawancara yang dapat diuraikan sebagai berikut:

1. Observasi (Pengamatan)

Dilakukan pada saat proses pembelajaran berlangsung dengan mengamati secara cermat tentang apa yang terjadi dengan menggunakan empat lembar observasi (pengamatan) yaitu lembar:

a) Pengamatan yang dilakukan pada proses pembelajaran,

b) Kegiatan guru,

c) Kegiatan siswa,

d) Respon siswa dan perkembangan kemampuan mengenal huruf siswa.

Pada tahap ini, guru mengamati dampak atau hasil dari tindakan yang dilaksanakan terhadap siswa. Pengamatan dilakukan secara cermat dan dilakukan pencatatan-pencatatan berdasarkan lembar observasi yang telah disiapkan

2. Wawancara/Interview

Menurut Esterberg (2002) wawancara adalah merupakan pertemuan dua orang untuk bertukar informasi dan ide melalui tanya jawab, sehingga dapat dikonstruksikan makna dalam suatu topik tertentu, dan wawancara dibagi tiga 
yaitu: wawancara terstruktur/structured interview, semiterstruktur /semistructure interview, dan tidak terstruktur /unstructured interview.(Sugiyono, 2010: 317319). Wawancara dalam penelitian ini menggunakan wawancara tidak terstruktur yaitu wawancara yang bebas dimana peneliti tidak menggunakan pedoman wawancara yang digunakan hanya berupa garis-garis besar permasalahan yang akan ditanyakan (Sugiyono, 2010: 320).

\section{- Instrumen Penelitian}

Bentuk-bentuk instrumen adalah sebagai berikut:

1) angket,

2) checklist, dan

3) rating scale.

\section{- Rancangan Penelitian}

Penelitian tindakan ini dilaksanakan dalam dua siklus kegiatan yaitu siklus 1 dan siklus 2. Masing-masing siklus terdiri 4 tahap kegiatan yaitu :

1. Menyusun rencana tindakan

2. Melaksanakan tindakan

3. Melakukan observasi

4. Membuat analisis dilanjutkan refleksi

Pada penelitian ini yang melaksanakan kegiatan mengajar adalah Kepala Taman Kanak-Kanak bersama-sama dengan guru kelompok B sekaligus sebagai observer

\section{HASIL PENELITIAN DAN PEMBAHASAN}

Sebelum dilakukan tindakan, peneliti melakukan pengamatan untuk mengetahui kondisi awal kemampuan berbahasa anak. Hal tersebut dilakukan dengan cara observasi khususnya dalam aspek bahasa kemudian peneliti membuktikan dengan mengamati anak melalui kegiatan mendengarkan/meyimak isi cerita, dan menyampaikan kembali isi cerita.

Kemampuan berbahasa anak dapat dilakukan dengan berbagai cara, salah satunya adalah dengan bercerita menggunakan gambar seri. Gambar seri dalam 
penelitian ini adalah media yang dari kertas berukuran A4, yang masing-masing gambar warna yang menarik.

Bermain dengan gambar seri. anak dapat mengenal bentuk dan bunyi huruf atau bahkan dapat menyebutkan kata yang tercantum di dalam cerita tersebut. Dari hasil penelitian tindakan kelas yang dilakukan selama 3 siklus yang terdiri dari 9 kali pertemuan, aspek kemampuan berbahsa anak mengalami peningkatan dari kondisi awal sebelum diadakan penelitian tindakan kelas hingga penelitian tindakan.

Peningkatan perkembangan kemampuan berbahasa anak kelompok B di TK Al Falah Kota Jambi jika dipersentase rata-rata dari kondisi awal 29,2\%, dan mencapai 83,3\% setelah dilakukan tindakan atau dari 7 anak menjadi 13 anak.

Hasil penelitian menunjukkan bahwa kemampuan berbahasa dapat ditingkatkan menggunakan kegiatan bercerita dengan menggunakan gambar seri. dalam penelitian ini sebagai alat peraga yang sangat membantu guru.

Hal ini sejalan dengan pendapat Andang Ismail bahwa dengan bantuan alat peraga, guru bukan saja dapat menjelaskan lebih banyak hal dalam waktu yang lebih singkat, juga dapat mencapai hasil yang lebih cepat, (Andang Ismail, 2006: 181). Dengan bantuan gambar seri, maka anak diharapkan dapat mengenal kata dengan cepat dengan cara yang menyenangkan.

Berdasarkan teori-teori yang telah dikemukakan, peneliti menyimpulkan bahwa kemampuan berbahasa dapat ditingkatkan melalui kegiatan bercerita dengan menggunakan gambar seri. Melalui gambar seri, selain anak mampu membaca juga mampu menyimak dan menyampaikan kemabali isi cerita Selain itu, gambar seri akan lebih efektif jika dibandingkan dengan bercerita tanpa menggunakan alat peraga. 
Data hasil penelitian perkembangan membaca

\begin{tabular}{|c|c|c|c|c|c|}
\hline \multirow[t]{2}{*}{ No. } & \multirow[t]{2}{*}{ Nama Anak } & \multicolumn{4}{|c|}{ Hasil Penelitian } \\
\hline & & BSB & $\overline{\mathrm{BSH}}$ & MB & $\mathrm{BB}$ \\
\hline 1. & Aulia & & & $\sqrt{ }$ & \\
\hline 2. & Alifia & & & $\sqrt{ }$ & \\
\hline 3. & Lirna & $\sqrt{ }$ & & & \\
\hline 4. & Afifah & $\sqrt{ }$ & & & \\
\hline 5. & Alisya & & & $\sqrt{ }$ & \\
\hline 6. & Arif & $\sqrt{ }$ & & & \\
\hline 7. & Muhammad & & $\sqrt{ }$ & & \\
\hline 8. & Ziqri & & $\sqrt{ }$ & & \\
\hline 9. & Azka & & & $\sqrt{ }$ & \\
\hline 10. & Fahri & $\sqrt{ }$ & & $\sqrt{ }$ & \\
\hline 11. & Sauki & & & $\sqrt{ }$ & \\
\hline 12. & Viola & & & $\sqrt{ }$ & \\
\hline 13. & Indira & $\sqrt{ }$ & & & \\
\hline 14. & Fakhri & $\sqrt{ }$ & & & \\
\hline 15 & Khalisa & & $\sqrt{ }$ & & \\
\hline 16 & Siti & & & $\sqrt{ }$ & \\
\hline 17 & Kaila & & & $\sqrt{ }$ & \\
\hline
\end{tabular}

Keterangan :

(BB) Belum Berkembang 0\% - 25\%

(MB) Mulai Berkembang 26\% - 50\%

(BSH) Berkembang Sesuai Harapan 51\%-75\%

(BSB) Berkembang Sangat Baik 76\% - 100\% 


\section{E. KESIMPULAN DAN SARAN}

\section{Kesimpulan}

Berdasarkan hasil penelitian dan pembahasan dalam penelitian ini dapat disimpulkan bahwa kemampuan membaca pada anak kelompok B dapat ditingkatkan menggunakan media kartu huruf dalam proses pembelajaran cara masing-masing anak membawa/memegang kartu huruf secara langsung

Hasil penelitian menunjukkan bahwa ada peningkatan kemampuan membaca yaitu pada kondisi awal sebesar 29,2\%, meningkat pada Siklus I menjadi 58,3\%, dan Siklus II meningkat menjadi 63,3\%. Dan pada siklus III meningkat menjadi 83,5 \%. Hal ini menunjukkan bahwa anak-anak di TK Al Falah II Kota Jambi telah mencapai kemampuan mengenal huruf pada kriteria baik seperti yang diharapkan.

Pembelajaran dalam meningkatkan kemampuan membaca dikatakan berhasil, karena dari 17 anak yang sudah mencapai pada kriteria baik sebanyak 13 anak $(83.5 \%)$.

\section{B. Saran}

Berdasarkan hasil penelitian dan kesimpulan di atas, peneliti memberikan saran berikut ini :

\section{Bagi Orangtua}

Bagi orang tua Disarankan agar sering bercerita dengan menggunakan media gambar seri dan media lainnya dalam mengenalkan dan meningkatkan kemampuan berbahsa sejak dini agar anak dapat bereksplorasi, menambah pengalaman, dan wawasan baru untuk meningkatkan kemampuan persiapan membaca untuk melnjutkan ke pendidikan lebih lanjut .

\section{Bagi Guru TK}

Disarankan bagi guru agar dapat menggunakan media gambar seri dalam proses kegiatan belajar mengajar untuk meningkatkan kemampuan membaca

\section{Bagi Kepala Sekolah}

Kepala sekolah perlu memfasilitasi media pembelajaran seperti buku-buku bacaan sesuai dengan jumlah kelas dan tiap kelas minimal 4 set untuk 
mempermudah guru dalam memberikan pemahaman dalam aspek bahasa juga mempermudah anak kelompok B dalam persiapan membaca.

4. Bagi peneliti lain

Bagi peneliti lain agar dapat meneliti dengan berbagai media dengan bentuk dan ukuran yang lebih bervariasi dalam meningkatkan kemampuan berbahsa maupun meningkatkan kemampuan lainnya seperti: kemampuan berbicara dan kemampuan membaca awal anak.

\section{DAFTAR PUSTAKA}

Arikunto Suharsimi, dkk. 2017. Penelitian Tindakan Kelas Edisi Revisi. Jakarta:

Bumi Aksara. Dhieni, Nurbiana dkk. 2005. Metode Pengembangan Bahasa. Jakarta: Universitas Terbuka.

Djamarah Syaiful Bahri. 2011. Psikologi Belajar. Jakarta: PT Rineka Cipta.

Kunandar. 2008. Langkah Mudah Penelitian Tindakan Kelas Sebagai Pengembangan Profesi Guru. Jakarta : PT. Raja Grafindo Persada.

Moeslichatoen. 2004. Metode Pengajaran Di Taman Kanak-Kanak. Jakarta: PT Rineka Cipta.

Permendikbud. 2014. Standar Nasional Pendidikan Anak Usia Dini. Jakarta:

Permendikbud. Sugiyono. 2014. Metode Penelitian Kuantitatif Kualitatif dan $R \& D$. Bandung: Alfabeta.

Susanto Ahmad. 2017. Pendidikan Anak Usia Dini (Konsep dan Teori). Jakarta: Bumi Aksara.

Widiyanto, Joko. 2016. SPSS For Windows Untuk Analisis Data Statistik Dan Penelitian Untuk Analisis Data Statistik dan Penelitian. Surakarta: FKIP Universitas Muhammadiyah Surakarta.

Rika Ariyani, Editor Jurnal Literasiologi. Literasi Kita Indonesia. STAI Syekh Maulana Qori. Merangin Bangko.

Sumarto, D. S. (2018). Mewujudkan Sekolah Efektif Melalui Manajemen Mutu. Jurnal Al-Ashlah, 2(1). Diambil dari https://journal.staimaarifjambi.ac.id/index.php/alashlahjournal/article/view/127 